\title{
Modernisasi Sistem Pendidikan Pesantren Salafiyah
}

\author{
Nur Hidayah \\ IAI An Nur Lampung \\ Email: nurhidayah@an-nur.ac.id
}

\begin{abstract}
Absract
Pondok Pesantren has an effective role to form the character of human who have the characteristic and have Islamic values through transformation process of yellow book. Pesantren is a very important link for the transformation of science and the inheritance of Islamic values from the next generation of generation. Originally boarding school more known as Islamic educational institutions, the institutions used for the spread and study of Islam. Pondok Pesantren is an Islamic educational institution that puts the figure of Kyai as the central figure and the mosque as the center of the institution. The quality of pesantren education depends on the quality of kyai as social actors, mediators, dynamists, catalysts, motivators as well as power with the depths of kyai knowledge and new insights . Because with new insights a kyai will quickly anticipate the existence of an opinion that says that the output of boarding school students is not qualified, then kyai anticipate the changes in all fields according to the needs of the community
\end{abstract}

Keyword: Modernization, Salafiyah Pesantren Education

\section{Pendahuluan}

Pendidikan adalah kewajiban bagi umat muslim. Sebagai sebuah kewajiban bagi umat muslim serta berfungsi sebagai media tempat berlangsungnya proses interaksi sosial yang menjadikan dirinya sebagai generator perubahan dalam masyarakat.

Perkembangan globalisasi abad mutakhir menghendaki adanya suatu sistem pendidikan yang komprehensif.Pendidikan merupakan modal dasar dalam pembangunan yang tentunya akan menentukan kemajuan dan perkembangan suatu bangsa. Pendidikan mendorong potensi dan sumber daya setiap individu untuk dapat terus dikembangkan. Pendidikan yang baik diharapkan akan membentuk kepribadian manusia yang sadar akan tanggung jawabnya sebagai makhluk individu, makhluk susila, makhluk sosial dan makhluk beragama serta memiliki karakter yang baik dan bermartabat.

Pendidikan harus menjadi prioritas utama dalam pembangunan bangsa Indonesia yang lebih baik, maju dan berkembang dimasa yang akan datang. Pasal 1, UU Sisdiknas, No. 20, Tahun 2003, menyatakan bahwa: Pendidikan adalah usaha sadar dan terencana untuk mewujudkan suasana belajar dan iproses pembelajaran agar peserta didik secara aktif mengembangkan potensi dirinya untuk memiliki kekuatan spiritual keagamaan, pengendalian diri, kepribadian, kecerdasan, akhlak mulia serta keterampilan yang diperlukan dirinya, rnasyarakat, bangsa dan Negara.

Perkembangan masyarakat menghendaki adanya pembinaan anaknya dilakukan secara seimbang antara tingkah nilai dan akhlak, pengetahuan, kecerdasan, keterampilan, kemampuan komunikasi, dan sikap terhadap 
lingkungan, dengan kata lain antara ilmu pengetahuan teknologi Iman dan Takwa harus seimbang dimiliki oleh anak sekarang. ${ }^{1}$

Globalisasi pendidikan merupakan lintas batas yang menerobos dinding geografis, kebangsaan, kebudayaan bahkan peradapan bangsa-bangsa sehingga pendidikan sebagai muatan globalisasi, tidak dapat dicegah lagi oleh Negara dan masyarakat dunia manapun. Globalisasi sendiri mempunyai dampak negatif antaralain (1) dapat melunturkan identitas suatu bangsa, (2)kurang kesadaran atas wawasan nusantara, dan kurangnya eksis terhadap budaya etnik. ${ }^{2}$

Dampak negatif tersebut perlu diantisipasi secara aktif dan efektif karena dapat melahirkan ancaman terhadap budaya lokal dan pendidikan lokal karena secara personal maupun institusional pendidikan perkembangan globalisasi perlu dipersiapkan secara keilmuan mendalam kelembagaan pendidikan profesional. Sistem pendidikan di Indonesia menjadi dualisme pendidikan yaitu lembaga pendidikan yang disebut sekolah umum dan lembaga pendidikan yang berbasiskan agama, termasuk kedalam lembaga pendidikan Agama yaitu madrasah, Perguruan tinggi Agama dan Pondok Pesantren. Pesantren merupakan bentuk lembaga pendidikan Agama yang spesifik di Indonesia. ${ }^{3}$ Pondok Pesantren sebagai salah satu lembaga pendidikan tertua di tanah air. Sedangkan di Lampung tercatat memiliki 750 pondok pesantren dengan 101.134 santri. ${ }^{4}$ Dari segi proses penyajian materi, pendidik dan anak didik, lembaga pendidikan. Pesantren secara fisik, biasanya dilengkapi oleh sarana-sarana seperti : Masjid rumah kiyai, tempat pemondokan dan istirahat keluarga, santri dan kitab kuning. Demikian pula halnya dengan bangunan Masjid yang letaknya selalu berdekatan dengan rumah kiyai tersebut tidak hanya dijadikan tempat shalat akan tetapi merupakan bangunan utama untuk melaksanakan pendidikan. Pondok pesantren dengan para santrinya merupakan asset yang sangat berarti dalam pembangunan bila diberdayakan secara obtimal, karena pondok pesantren tidak hanya memberikan kontribusi dibidang pendidikan agama, tetapi juga dibidang iptek, pertanian, budaya dan lainya.

Pondok pesantren mempunyai peran efektif membentuk karakter manusia yang bercirikhas serta memiliki nilai-nilai islam melalui proses transformasi kitab kuning. Pesantren menjadi penghubung yang amat penting bagi tansformasi keilmuan dan pewarisan nilai-nilai islam dari generasi kegenerasi berikutnya. Semula pondok pesantren lebih dikenal sebagai lembaga pendidikan islam, yakni lembaga yang digunakan untuk penyebaran dan mempelajari agama Islam. ${ }^{\text {Pondok }}$ pesantrenmerupakan lembaga pendidikan

${ }^{1}$ Ridlwan Nasir, Mencari Tipologi Format Pendidikan Ideal Pondok Pesantren di Tengah Arus Perubahan, ( Yogyakarta; Pustaka Pelajar, 2005). h 1

2 Mohammad Fakry Gaffar, Internasionalisasi Program Pendidikan Guru dalam Hukum Manajemen Corporate dan Strategi pemasaran Jasa Pendidikan, (Jakarta; Alfabeta Bandung,2009) h.5

${ }^{3}$ Manfred Ziemek, Pesantren dalam Perubahan Sosial, (Jakarta;P3M,2005), h. 7

${ }^{4}$ Lampung Post, Pendidikan Pesantren bangun Karakter, Rabu 18 juni 2014

${ }^{5}$ Suyoto, Pondok pesantren dalam Alam Pendidikan Nasional (Jakarta; LP3S, 2005 h. 61 Dawam Rahardjo, Perkembangan Masyarakat dalam perspektif Pesantren, dalam Pergulatan Dunia Pesantren Membangun dari Bawah( Jakarta;P3M,2005),dan lihat Sudjoko Prasojo, Profil Pesantren (Jakarta; LP3S) h. 1

| RI'AYAH, Vol. 4 No. 01 Januari-Juni 2019 
Islam yang menempatkan sosok Kyai sebagai tokoh sentral dan masjid sebagai pusat lembaganya. ${ }^{6}$

Kualitas dari pendidikan pesantren tergantung pada kualitas kyai sebagai sosial aktor, mediator, dinamisator,katalisator, motivator maupun sebagai power(kekuatan) dengan kedalaman ilmu kyai dan wawasan barunya. Karena dengan wawasan baru seorang kyai akan cepat mengantisipasi adanya suatu pendapat yang mengatakan bahwa keluaran santri pondok pesantren tidak berkualitas, lalu kyai mengadakan antisipasi dengan perubahan-perubahan disegala bidang sesuai dengan kebutuhan masyarakat.

Ilmu-ilmu agama Islam digunakan secara kreatif untuk melakukan antisipasi terhadap kebutuhan-kebutuhan akan perubahan. Disamping sebagai alat penentu mana bagian yang esensial dari kehidupan yang tidak dapat ditawar-tawar lagi dan harus dipertahankan. ${ }^{7}$

Keberadaan pesantren juga memiliki peranan sebagai salah satu benteng perlawanan terhadap kolonialisme dan feodalisme. Peranan multifungsi pesantren di Indonesia ini dimulai sejak perang melawan penjajah di era kolonialisme, hingga menjadi penyumbang pemikiran konstruktif dalam pembangunan bangsa diera globalisasi. ${ }^{8}$

Zaman globalisasi memberikan peluang yang besar bagi pesantren untuk mentransformasikan nilai-nilai Islam yang universal yang rahmatan lil alamiin ke dalam aktualisasi kehidupan nyata. Pesantren memiliki peran yang multidimensional; pendidikan, keagamaan yang mempertahankan nilai-nilai Islam, pengembangan, penyadaran dan penguatan civil society.

Menyelesaikan persoalan-persoalan sosial kemasyarakatan dengan perspektif agama menjadikan dirinya sebagai lembaga pendidikan yang berbasis komunitas lokal dengan kualitas global/internasional. Pesantren dapat melakukan percepatan pembangunan kualitas sumberdaya manusia tanpa kehilangan nilai- nilai spiritualitasnya.Maka perlu pendidikan berbasis masyarakat sebagai penyelenggaraan pendidikan berdasarkan kekhasan agama, sosial,

budaya, aspirasi, dan potensi masyarakat sebagai perwujudan pendidikan dari, oleh, dan untuk masyarakat. ${ }^{9}$

Keunggulan pesantren terletak pada prinsip memanusiakan manusia dalam proses pembelajaranya dan menggabungkan tri pusat pendidikan (keluarga, sekolah dan masyarakat) dalam lingkunganya agar dapat mencetak para santri yang memiliki karakter kuat baik sisi keilmuan agama umum maupun prilaku sehari-hari. ${ }^{10}$ Maka dari sinilah pendidikan yang berlatar belakang pondok pesantren mempmyai peranan penting dalam menumbuh kembangkan akhlak seseorang. Pesantren adalah Salah satu bentuk dari lembaga pendidikan yang mengajukan pengajarannya pada nilai-nilai islami yang terintegrasi. Pesantren merupakan institusi pendidikan Islam tertua di tanah air

6 Dawam Raharjo, "Pesantren dan Pembaharuan", cet.V, (Jakarta; LP3ES, 1995), 87

${ }^{7}$ Ridlwan Nasir, Mencari Tipologi Format Pendidikan Ideal Pondok Pesantren di Tengah Arus Perubahan, ( Yogyakarta; Pustaka Pelajar, 2005). h 8

${ }^{8} \mathrm{M}$. Ihsan Dacholfany, Pendidikan Karakter Belajar Ala Pesantren Gontor (Depok; Wafimediatama,2014) h.8

${ }^{9}$ UU Sisdiknas

${ }^{10}$ M. Ihsan Dacholfany, Pendidikan Karakter...,h.8

| RI'AYAH, Vol. 4 No. 01 Januari-Juni 2019 
mampu yang memberikan andil sangat besar dalam mencerdaskan kehidupan umat dan bangsa. Proses belajar mengajar di pesantren tradisional/salafiyah tidak mengalami dinamika dan tidak memperhitungkan waktu, strategi, metode yang lebih kontekstual dengan perkembangan zaman. Padahal seiring berkembangnya zaman santri membutuhkan formalitas-sebutlah ijazah serta penguasaan bidang keahlian tertentu yang dapat mengantarkannya agar mampu menjalani kehidupan. Di era modern santri tidak hanya bermodal nilai dan norma moral saja, tetapi perlu skill yang mumpuni agar menjadi bekal di masa depan. Perkembangan metode dalam pembelajaran membuat santri tidak berpaku pada metode tertentu, sehingga ketika sudah selesei hanya dapat menerapkan metode tertentu saat terjun pada sekolah atau madrasah.Konsep kurikulum yang tidak tertata rapi sehingga keterserapan lulusan pondok pesantren salafiyah kurang dibandingkan pondok pesantren modern.Kelebihan belajar di pesantren salaf yaitu adanya budaya tadzim pada kiai dan patuh segala apa yang diajarkan oleh kiai. Sekiranya itu merupakan hal yang baik. Karena pesantren salafiyah lebih menonjol pada pendidikan agama dan akhlaknya, maka pesantren ini kurang mempersiapkan para santri menghadapi isu-isu sosial yang lebih luas dalam suatu masyarakat yang semakin berubah.

\section{B. Modernisasi Sistem Pendidikan}

\section{Pengertian Modernisasi Pendidikan}

Modernisasi berasal dari kata modern yang berarti terbaru, mutakhir, atau sikap dan cara berpikir yang sesuai dengan tuntutan zaman. Selanjutnya modernisasi diartikan sebagai proses pergeseran sikap dan mentalitas sebagai warga masyarakat untuk bisa hidup sesuai dengan tuntutan masa kini. Modernisasi merupakan suatu proses yang ditandai dengan implementasi ilmu pengetahuan dan teknologi dalam segala segi kehidupan masyarakat . ${ }^{11}$ Dari pemaparan di atas, dapat dipahami bahwa modernisasi adalah suatu usaha secara sadar untuk menyesuaikan diri dengan konstelasi dunia dengan menggunakan kemajuan ilmu pengetahuaan, untuk kebahagiaan hidup sebagai perorangan, bangsa, atau umat manusia. Modernisasi atau inovasi pendidikan pesantren dapat diartikan sebagai upaya untuk memecahkan masalah pendidikan pesantren. Atau dengan kata lain, inovasi pendidikan pesantren adalah suatu ide, barang, metode yang dirasakan atau diamati sebagai hal yang baru bagi seseorang atau sekelompok orang, baik berupa hasil penemuan (invention) maupun discovery, yang digunakan untuk mencapai tujuan atau memecahkan masalah pendidikan pesantren.

Gagasan modernisasi dianggap perlu dilakukan oleh beberapa kalangan, salah satunya adalah Nur Cholis Majid. Ia berpendapat bahwa modernisasi ini sebaiknya dilakukan dengan model sistem pendidikan Pesantren Modern Gontor Ponorogo. Menurut Nur Cholis Majid, yang paling penting untuk direvisi adalah kurikulum pesantren yang biasanya mengalami penyempitan orientasi kurikulum. Maksudnya, dalam pesantren terlihat materinya hanya khusus yang disajikan dalam bahasa Arab. Mata pelajarannya meliputi fiqh, aqa'id, nahwu-

11 Sanggar Kanto, Modernisasi dan Perubahan Sosial (Suatu Kajian dari Perspektif Teori dan Empirik). Malang: Fakultas Pertanian Universitas Brawijaya, 2006. h.3

| RI'AYAH, Vol. 4 No. 01 Januari-Juni 2019 
sharf, dan lain-lain. Sedangkan tasawuf dan semangat keagamaan yang merupakan inti dari kurikulum keagamaan cenderung terabaikan. ${ }^{12}$

Tasawufhanya dipelajari sambil lalu saja, tidak secara sungguh-sungguh. Padahal justru inilah yang lebih berfungsi dalam masyarakat zaman modern. Disisi lain, pengetahuan umum nampaknya masih dilaksanakan secara setengahsetengah, sehingga kemampuan santri biasanya samgat terbatas dan kurang mendapat pengakuan dari masyarakat umum. Maka dari itu, Cak Nur menawarkan kurikulum Pesantren Modern Gontor sebagai model modernisasi pendidikan pesantren.

Miles mencontohkan inovasi (modernisasi) pendidikan adalah sebagai berikut: Bidang personalia. Pendidikan yang merupakan bagian dari sistem sosial, tentu menentukan personel sebagai komponen sistem. Inovasi yang sesuai dengan komponen personel misalnya adalah peningkatan mutu guru, sistem kenaikan pangkat, dan sebagainya. Dalam hal ini, pesantren telah di bantu dengan adanya program Beasiswa S1 untuk guru diniyah oleh Departemen Agama.

Fasilitas fisik. Inovasi pendidikan yang sesuai dengan komponen ini misalnya perubahan tempat duduk, perubahan pengaturan dinding ruangan perlengkapan Laboratorium bahasa, laboratorium Komputer, dan sebagainya. Pengaturan waktu. Suatu sistem pendidikan tentu memiliki perencanan penggunaan waktu. Inovasi yang relevan dengan komponen ini misalnya pengaturan waktu belajar, perubahan jadwal pelajaran yang dapat memberi kesempatan siswa/mahasiswa untuk memilih waktu sesuai dengan keperluannya, dan lain sebagainya. ${ }^{13}$

Dengan adanya modernisasi sistem pendidikan pesantren salafiyah diharapkan adanya kemajuan diberbagai bidang pada pondok pesantren tersebut. Tujuan yang diharapkan adalah terciptanya kondisi yang nyaman, aman dan sistem pembelajaran yang tepat dan sesuai perkembangan zaman guna terciptanya kualitas santri yang bagus dan berguna bagi semua aspek kehidupan

Pandangan para ahli mengenai pendidikan yang lazim digunakan pada praktek pendidikan. Pendidikan sering diidentikan dengan usaha orang dewasa secara sadar untuk membimbing dan mengembangkan kepribadian serta kemampuan dasar anak didik baik dalam bentuk pendidikan formal maupun non formal. ${ }^{14}$ Selain itu, pendidikan juga berupa bimbingan atau pimpinan secara sadar oleh si pendidik terhadap perkembangan jasmani dan rohani si terdidik menuju terbentuknya kepribadian yang utama. ${ }^{15} \mathrm{Hal}$ senada juga ditegaskan oleh Soegarda Poerbakawatja, pendidikan merupakan semua perbuatan atau usaha dari generasi tua untuk mengalihkan pengetahuannya,

12 Malik, Jamaludin. Pemberdayaan Pesantren, Menuju Kemandirian dan Profesionalisme Santri dengan Metode Daurah Kebudayaan, Yogyakarta: Pustaka Pesantren, 2005. h.28

13Iskandar, Muhaimin. Gus Dur, Islam dan Kebangkitan Indonesia, Cet.I. Jakarta: Klik R. 2007 1976), h. 12

${ }^{14} \mathrm{HM}$. Arifin, Hubungan Timbal Balik Pendidikan Agama, (Jakarta: Bulan Bintang,

${ }^{15}$ Ahmad D. Marimba, Pengantar Filsafat Pendidikan (Bandung: Al Ma'arif, 1989), h. 19.

| RI'AYAH, Vol. 4 No. 01 Januari-Juni 2019 
pengalamannya, kecakapannya, dan ketrampilannya kepada generasi muda. Sebagai usaha menyiapkan agar dapat memenuhi fungsi hidupnya baik jasmani maupun rohani. ${ }^{16}$

Dengan demikian, dari beberapa pendapat tersebut dapatlah disimpulkan bahwa pendidikan pada hakekatnya merupakan usaha manusia untuk dapat membantu, melatih, dan mengarahkan anak melalui transmisi pengetahuan, pengalaman, intelektual, dan keberagamaan orang tua (pendidik) dalam kandungan sesuai dengan fitrah manusia supaya dapat berkembang sampai pada tujuan yang dicita-citakan yaitu kehidupan yang sempurna dengan terbentuknya kepribadian yang utama.

Selanjutnya, istilah pendidikan Islam terdiri dari dua kata "pendidikan" dan "Islam". Pada kontek ini, tampaknya kata "Islam" menjadi Keywords yang berfungsi sebagai sifat, penegas dan pemberi ciri khas pada kata "pendidikan". Dengan demikian pendidikan Islam merupakan pendidikan yang secara khas memiliki ciri Islami, berbeda dengan konsep atau mode pendidikan yang lain.

Sebagai suatu agama, Islam memiliki ajaran yang diakui lebih sempurna dan kompherhensif dibandingkan dengan agama-agama lainnya yang pernah diturunkan Tuhan sebelumnya. Islam tidak hanya mengatur cara mendapatkan kebahagiaan hidup di akhirat, melainkan juga mengatur cara mendapatkan kebahagiaan hidup di dunia termasuk di dalamnya mengatur masalah pendidikan.

Islam sebagai agama yang ajaran-ajarannya bersumber pada al- Qur'an dan Hadist sejak awal telah menancapkan revolusi di bidang pendidikan dan pengajaran. Langkah yang tersebut pada akhirnya amat strategis dalam upaya mengangkat martabat kehidupan manusia. Kini diakui dengan jelas, pendidikan merupakan jembatan yang menyeberangkan orang dari keterbelakangan menuju kemajuan, dari kehinaan menuju kemuliaan serta dari ketertindasan menjadi merdeka dan seterusnya.

Dalam hal ini pengertian pendidikan Islam diartikan sebagai bimbingan jasmani maupun rohani berdasarkan hukum-hukum agama Islam menuju terbentuknya kepribadian utama menurut ukuran-ukuran Islam. ${ }^{17}$ Senada dengan itu, Chabib Thoha memberikan pengertian bahwa pendidikan Islam sebagai falsafah dasar dan tujuan serta teori-teori yang dibangun untuk melaksanakan praktek pandidikan berdasarkan nilai-nilai dasar Islam yang terkandung dalam Al-Qur'an dan Hadits. ${ }^{18}$

Pendidikan Islam adalah segala usaha untuk memelihara dan mengembangkan fitrah manusia serta sumber daya insan yang berada pada subjek didik menuju terbentuknya manusia seutuhnya (insan kamil) sesuai dengan norma Islam atau dengan istilah lain yaitu terbentuknya kepribadian muslim. ${ }^{19}$

${ }^{16}$ Soegarda Poerbakawatja, et. al. Ensiklopedi Pendidikan, (Jakarta: Gunung Agung, 1981), h. 257

${ }^{17}$ Ahmad D. Marimba,Pengantar..., h. 21

${ }^{18}$ Chabib Thoha, Kapita Selekta Pendidikan Islam, (Yogyakarta: Pustaka Pelajar, 2007), h. 99

${ }^{19}$ Achmadi, Islam Sebagai Paradigma Ilmu Pendidikan, (Yogyakarta: Aditya media, 2007), h. 14.

| RI'AYAH, Vol. 4 No. 01 Januari-Juni 2019 
Sebagai ajaran (doktrin) Islam mengandung sistem nilai, dimana proses pendidikan Islam berlangsung dan dikembangkan secara konsisten menuju tujuannya. Sejalan dengan pemikiran ilmiah dan filosofis dari pemikir-pemikir sesepuh muslim, maka sistem nilai-nilai itu kemudian dijadikan dasar bangunan (struktur) pendidikan Islam yang memiliki daya lentur normatif menurut kebutuhan dan kemajuan.

Pendidikan Islam mengidentifikasi sasarannya yang digali dari sumber ajarannya yaitu Al-Quran dan Hadist, meliputi empat pengembangan fungsi manusia:

1) Menyadarkan secara individual pada posisi dan fungsinya ditengahtengah makhluk lain serta tanggung jawab dalam kehidupannya.

2) Menyadarkan fungsi manusia dalam hubungannya dengan masyarakat, serta tanggung jawabnya terhadap ketertiban masyarakatnya.

3) Menyadarkan manusia terhadap pencipta alam dan mendorongnya untuk beribadah kepada-Nya.

4) Menyadarkan manusia tentang kedudukannya terhadap makhluk lain dan membawanya agar memahami hikmah tuhan menciptakan makhluk lain, serta memberikan kemungkinan kepada manusia untuk mengambil manfaatnya. ${ }^{20}$

Tentu saja masih banyak lagi uraian pengertian pendidikan Islam menurut para ahli, namun dari sekian banyak pengertian pandidikan Islam yang dapat kita petik, pada dasarnya pendidikan Islam adalah usaha bimbingan jasmani dan rohani pada tingkat kehidupan individu dan sosial untuk mengembangkan fitrah manusia berdasarkan hukum-hukum Islam menuju terbentuknya manusia ideal (insan kamil) yang berkepribadian muslim dan berakhlak terpuji serta taat pada Islam sehingga dapat mencapai kebahagiaan didunia dan di akherat.

Dari berbagai uraian diatas kiranya dapat penulis tarik sebuah benang merah, bahwa Pendidikan Islam itu merupakan suatu kajian mengenai masalah yang terdapat dalam kegiatan pendidikan yang didasarkan pada al-Qur'an dan Hadist sebagai sumber primer dan pendapat-pendapat para ahli, khususnya para filosof Muslim, sebagai sumber sekunder. Dengan demikian, pendidikan Islam secara singkat dapat dikatakan adalah pendidikan yang berdasarkan ajaran Islam atau pendidikan yang dijiwai oleh ajaran Islam.

\section{Islam dan Sistem Pendidikan Modern}

Muhammad Fathurrohman, akademisi UIN Maliki Malang, mendefinisikan pendidikan sebagai sebuah aktifitas manusia yang memiliki maksud tertentu, yang diarahkan untuk mengembangkan individu sepenuhnya. Konsep pendidikan islam tidak dapat sepenuhnya dipahami tanpa lebih dulu memahami penafsiran islam tentang pengembangan individu sepenuhnya. Hanya melalui perbandingan konsep manusia dan pengembangannya dengan berbagai konsep yang timbul dalam masyarakat modern, barulah kita dapat memahami sifat berbagai problem yang kita hadapi dan cara menjawabnya. Adapun tujuan akhir pendidikan muslim adalah perwujudan penyerahan

${ }^{20 I b r a h i m ~ B R, ~ " F i l s a f a t ~ P e n d i d i k a n ~ I s l a m ", ~ A r t i k e l ~ d a l a m ~ h t t p: / / i b r a h i m b r . ~}$ blogspot. com/ di download pada 02 Februari 2017

| RI'AYAH, Vol. 4 No. 01 Januari-Juni 2019 
mutlak kepada Allah, pada tingkat individual, masyarakat dan kemanusiaan pada umumnya .

Dengan demikian, modernisasi dapat dikatakan "memaksa" proses kurikulum, cara, metodologi, situasi dan pendidikan Islam dari yang tradisional (ortodox) kearah yang lebih rasional, dan professional sejalan dengan perkembangan ilmu pengetahuan dan teknologi saat ini. Kemoderenan ini cenderung menghasilkan jebakan baru yang bernama cultural shock, virus langka namun mematikan ini lambat laun ikut andil dalam penyelenggaraan sistem pendidikan Islam. Para pelaku sumber daya kependidikan Islami seakan tak sadar mereka telah terjebak, Mereka mengabaikan sebuah penawar yang sangat ampuh, yaitu 'amar ma'ruf, nahi munkar dan melalaikan sumber segala hukum, Al-Qur'an dan Hadits.

Memang saat ini banyak lembaga pendidikan Islam yang telah berhasil menjalankan sistem kemoderenan tanpa mengabaikan nilai-nilai Islami yang hakiki, namun itu hanya sebagian dan tak bisa dijadikan barameter langsung, sebab sebagian lainnya cenderung terperangkap jebakan cultural shock dan akhirnya berkiblat pada prinsip sekularisme-nya "orang barat", yaitu pemisahan Ilmu pengetahuan dengan Pemilik ilmu pengetahuan.

\section{Modernisasi Pendidikan Islam di Indonesia}

Di Indonesia sendiri perkembangan pendidikan Islam pada awalnya masih dilaksanakan secara tradisional belum tersusun kurikulum seperti saat ini. Baik itu pendidikan di surau maupun pesantren. Modernisasi pendidikan Islam di Indonesia sangat di perlukan. Modernisasi pendidikan Islam diakui tidaklah bersumber dari kalangan Muslim sendiri, melainkan diperkenalkan oleh pemerintahan kolonial belanda pada awal abad 19. Program yang dilaksanakan oleh kolonial Belanda adalah dengan mendirikan Volkshoolen, sekolah rakyat, atau sekolah desa (Nagari) dengan masa belajar selama 3 tahun, di beberapa tempat di Indonesia sejak dasawarsa 1870-an. Pada tahun 1871 terdapat 263 sekolah dasar semacam itu dengan siswa sekitar 16.606 orang; dan menjelang 1892 meningkat menjadi 515 sekolah dengan sekitar 52.685 murid Point penting eksprimen Belanda dengan sekolah nagari terhadap system dan kelembagaan pendidikan Islam adalah tranformasi sebagian surau di Mingkabau menjadi sekolah nagari model Belanda. Memang berbeda dengan masyarakat muslim jawa umumnya memberikan respon yang dingin, banyak kalangan masyarakat muslim Minangkabau memberikan respon yang cukup baik terhadap sekolah desa . Perbedaan respon masyarakat Muslim Minangkabau dan jawa banyak berkaitan dengan watak cultural yang relatif berbeda, selain itu juga berkaitan dengan pengalaman historis yang relatif berbeda baik dalam proses dan perkembangan Islamisasi maupun dalam berhadapan dengan kekuasaan Belanda.

Selain itu perubahan atau modernisasi pendidikan Islam juga datang dari kaum reformis atau modernis Muslim. Gerakan reformis Muslim yang menemukan momentumnya sejak abad 20 berpendapat, diperlukan reformasi system pendidikan Islam untuk mempu menjawab tantangan kolonialisme dan ekspansi Kristenisasi.

\section{Konsep Pondok Pesantren}

\section{Pengertian Pondok Pesantren}

Di Indonesia berkembang macam-macam jenis lembaga pendidikan baik formal maupun tidak formal. Hal itu dipengaruhi oleh pesatnya penduduk 
Indonesia yang bergama Islam. Di antara lembaga pendidikan yang pernah muncul di Indonesia, pendidikan keagamaan dalam bentuk pesantren merupakan sistem pendidikan tertua saat ini dan dianggap sebagai produk budaya Indonesia yang indigenoous (makna keaslian Indonesia). Pendidikan ini semula merupakan pendidikan agama Islam yang dimulai sejak munculnya masyarakat Islam di Nusantara pada abad ke-13.

Beberapa abad kemudian penyelenggaraan pendidikan ini semakin teratur dengan munculnya tempat-tempat pengajian. Bentuk ini kemudian berkembang dengan pendirian tempat-tempat menginap bagi para pelajar (santri), yang kemudian disebut pesantren.Akar historis-kultural pesantren tidak terlepas dari masuk dan berkembanganya Islam di Indonesia pada abad ke-13 yang bercorak sufistik atau mistik. Dalam pergumulannya, pesantren banyak menyerap budaya masyarakat Jawa Kelurahan pada saat itu yang cenderung statis dan sinkretis. Oleh karena itulah, disamping karena basis pesantren adalah masyarakat atau Islam tradisional.

Kata pondok berasal dari kata arab "funduq" yang artinya ruang tidur atau wisma atau hotel sederhana. Sedangkan kata pesantren berasal dari kata santri yang di imbuhi awalan pe- dan akhiran -an yang berarti menunjukkan tempat, maka artinya adalah tempat para santri. Terkadang juga di anggap sebagai gabungan kata santri (manusia baik) dengan suku kata (suka menolong), sehingga kata pesantren dapat berarti tempat pendidikan manusia baik-baik. Pesantren juga sering disebut dengan "Pondok pesantren" berasal dari kata santri. Menurut Kamus Umum bahasa Indonesia, kata ini mempunyai dua pengertian yaitu orang yang beribadat dengan sungguh-sungguh;orang saleh. Pengertian ini sering digunakan para ahli untuk membedakan golongan yang taat bergama dengan yang tidak taat. ${ }^{21}$

Pesantren juga memiliki dua arti yang dilihat dari segi fisik dan pengertian kultural. Dari segi fisik pesantren merupakan sebuah kompleks pendidikan yang terdiri dari susunan bangunan yang dilengkapi dengan sarana prasarana yang mendukung penyelenggaraan pendidikan. Sedangkan secara kultural pesantren mencakup pengertian yang lebih luas mulai dari system nilai khas yang secara intrinsik melekat di dalam pola kehidupan komunitas santri, seperti kepatuhan pada kyai sebagai tokoh sentral, sikap ikhlas dan tawadhu, serta tradisi keagamaan yang diwariskan secara turun-temurun.

Ada pula yang mengartikan pesantren dengan arti bahwa pesantren merupakan lembagapendidikan tradisional Islam untuk mempelajari, memahami, mendalami, menghayati, dan mengamalkan ajaran Islam dengan menekankan pentingnya moral keagamaan sebagai pedoman perilaku seharisehari. ${ }^{22}$

Bruinessen mengemukakan bahwa asal usul pesantren berasal dari Arab. Menurutnya pola pendidikan pesantren seperti pola pendidikan madrasah dan zawiyah di Timur Tengah. Jika madrasah dimaksudkan lembaga pendidikan

21 Nurcholish Madjid, Bilik-Bilik Pesantren sebuah Potret perjalanan, ( Jakarta: Paramadina, 1997), h.19-21

${ }^{22}$ Mastuhu, Dinamika sistem pendidikan Pesantren , (Jakarta:INIS,1994), h.55

| RI'AYAH, Vol. 4 No. 01 Januari-Juni 2019 
diluar masjid, maka zawiyah adalah lembaga pendidikan berbentuk lingkaran mengambil tempat disudut-sudut masjid. ${ }^{23}$

Pengertian Tradisional/ salafiyah menunjukkan bahwa lembaga ini hidup sejak ratusan tahun (300-400 tahun) yang lalu dan telah menjadi bagian yang mendalam dari sistem kehidupan sebagian besar umat Islam Indonesiayang merupakan golongan mayoritas bangsa indonesia dan telah mengalami perubahan dari masa ke masa sesuai dengan perjalanan umat bukan tradisional dalam arti tetap tanpa mengalami penyesuaian.

Kata salaf atau salafiyyah itu sendiri diambil dari numenklatur Arab salafiyyun untuk sebutan sekelompok umat Islam yang ingin kembali kepada ajaran Al-Qur'an dan Assunnah sebagaimana praktik kehidupan generasi pertama Islam (Assalafussholeh). Pada waktu itu umat Islam sedang mengalami perpecahan dalam bentuk golongan madzhab tauhid hingga beberapa kelompok.

Kelompok salafiyun ini mengaku lepas dari semua kelompok itu dan mengajak semua yang telah terkelompok-kelompok menyatu kembali kepada ajaran Al-Quran dan Assunnah. Penggunaan kata salaf juga dipakai untuk antonym kata salaf versus kholaf. Ungkapan ini dipakai untuk membedakan antara ulama salaf (tradisional) dan ulama kholaf (modern). Tidak selamanya yang salaf berarti kuno manakala ulama mengajak kembali kepada ajaran AlQur,an. Seringkali mereka bahkan lebih dinamis dari yang kholaf karena ulama kholaf banyak diartikan juga untuk menggambarkan ulama yang memiliki orientasi ke salafussholeh. ${ }^{24}$

Pondok pesantren salafiyah dapat dipahami sebagai pesantren yang memelihara bentuk pengajaran teks klasik dan pendidikan moral sebagai inti pendidikannya.Penggunaan kata salaf untuk pesantren hanya terjadi di Indonesia. Tetapi pesantren salaf cenderung digunakan untuk menyebut pesantren yang tidak menggunakan kurikulum modern, baik yang berasal dari pemerintah ataupun hasil inovasi ulama sekarang. Pesantren salaf pada umumnya dikenal dengan pesantren yang tidak menyelenggarakan pendidikan formal semacam madrasah ataupun sekolah. Kalaulah menyelenggarakan pendidikan keagaman dengan system berkelas kurikulumnya berbeda dari kurikulum, model sekolah ataupun madrasah pada umumnya.

Jadi menurut pesantren salaf yakni pesantren yang melakukan pengajaran terhadap santri-santrinya untuk belajar agama islam secara khusus tanpa mengikutsertakan pendidikan umum didalamnya. Kegiatan yang dilakukan biasanya mempelajari ajaran Islam dengan belajar menggunakan kitab-kitab kuning atau kitab kuno (klasik), yang menggunakan metode tradisional seperti hafalan, menerjemahkan kitab-kitab didalam berlangsungnya proses belajar mengajar. Dalam pesantren salaf peran seorang kyai atau ulama sangat dominan, kyai menjadi sumber referensi utama dalam system pembelajaran santrisantrinya.Pesantren tradisional (salafi) "merupakan salah satu lembaga pendidikan Islam yang sangat diperhitungkan dalam mempersiapkan ulama pada masa depan, sekaligus sebagai garda terdepan dalam memfilter dampak

${ }^{23}$ Martin Van Bruinessen, Kitab Kuning, Pesantren, dan Tarekat: Tradisi-tradisi Islam di Indonesia (Bandung: Mizan,1995),h. 22

${ }^{24}$ Sulthon masyhud, Khusnur Ridho, Manajemen Pondok Pesantren,(Jakarta:Diva Pustaka, 2003), h. 7

| RI'AYAH, Vol. 4 No. 01 Januari-Juni 2019 
negatif kehidupan modern". Istilah pesantren tradisional digunakan untuk menunjuk ciri dasar perkembangan pesantren yang masih bertahan pada corak generasi pertama atau generasi salafi.

\section{Karakteristik Pondok Pesantren}

Zamakhsyari Dhofier, mengatakan, ada lima unsur pondok pesantren yang melekat atas dirinya yang meliputi: masjid, pondok, pengajaran kitab-kitab Islam klasik, santri dan kiai. ${ }^{25}$

a. Santri

Kata santri yang digunakan untuk menunjuk peserta didik di pesantren berasal dari bahasa jawa "cantrik" yang berarti seseorang yang selalu mengikuti guru kemana pun pergi. Seorang cantrik mengikuti guru kemana saja untuk mempelajari ilmu yang dimiliki sang guru. ${ }^{26}$ Zamakhsyari Dhofir berpendapat bahwa: "Santri yaitu murid-murid yang tinggal di dalam pesantren untuk mengikuti pelajaran kitab-kitab kuning atau kitab-kitab Islam klasik yang pada umumnya terdiri dari dua kelompok santri yaitu: Santri Mukim yaitu santri atau murid-murid yang berasal dari jauh yang tinggal atau menetap di lingkungan pesantren. Santri Kalong yaitu santri yang berasal dari desa-desa sekitar pesantren yang mereka tidak menetap di lingkungan kompleks pesantren tetapi setelah mengikuti pelajaran mereka pulang.

\section{b. Kiai}

Istilah lain yang digunakan untuk menunjuk sang guru dipesantren adalah kiai juga dari bahasa Jawa. Perkataan "kiai' untuk laki-laki dan "nyai" untuk perempuan digunakan oleh orang Jawa untuk memanggil kakeknya. Kata "kiai" dan "nyai" di sini mengandung pengertian rasa hormat dan terhadap orang tua.

Didunia pesantren dikenal kiai dan guru bantu. Kiai dipahami sebagai pemilik dan pengasuh pondok pesantren yang bertugas mengajarkan pelajaranpelajaran agama, baik yang pokok maupun tambahan. Diantar yang poko adalah tauhid, fikih dan akhlak. Sedangkan guru bantu biasanya santri yang sudah menempuh pedidikan lama menggantikan sang kyai saad uzur atau halangan. Selain mengajar guru bantu juga menyediakan kebutuhan harian santri, menjadi pengurus harian serta menempatkan santri baru. ${ }^{27}$

c. Pondok

Menurut Manfred Ziemek, kata pondok berasal dari kata funduq (Arab) yang berarti ruang tidur atau wisma sederhana, karena pondok memang merupakan tempat penampungan sederhana bagi para pelajar yang jauh dari tempat asalnya. Bentuk bangunan asrama atau pondok tidak ada pola baku yang didikuti, karena itu bentuk asrama/pondok berbeda anatara satu pesantren

${ }^{25}$ Zamakhsyari Dhofier, Tradisi Pesantren Studi tentang Pandangan Hidup Kyai, (Jakarta: LP3S, 1983), h.18

${ }_{26}$ Abdullah Aly, Pendidikan Islam Multikultural di Pesantren, (Yogyakarta: Pustaka Pelajar, 2011), h.151-152

${ }^{27}$ Karel Steenbrink, Pesantren, Madrasah, dan Sekolah Pendidikan Islam dalam kurun Modern, (Jakarta: LP3ES,1986), h. 14 
dengan yang lain. Dari segi fungsinya, sistem pondok sebagai tempat tinggal para santri sesungguhnya merupakan komponen penting dari tradisi pesantren salafiyah, bahkan menjadi penopang utama bagi pesantren untuk dapat terus berkembang. Dengan sistem pondok ini, para santri merasa terjamin ketersediaan asrama, sehingga mereka tidak merasa kesulitan dari segi tempat tinggal.

d. Masjid

Bagi pondok pesantren, masjid tidak hanya berfungsi sebagai tempat beribadah sebagaimana pada umumnya. Akan tetapi juga berfungsi sebagai tempat belajar, mendidik para santri. Karena itu masjid merupakan komponen yang tidak dapat dipisahkan dari pesantren. Secara historis masjid merupakan transformasi dari lembaga pendidikan Islam salafiyah.

e. Pengajian Kitab Islam klasik

Pengajian kitab-kitab Islam klasik atau yang biasa disebut kitab kuning di pesantren sebenarnya upaya mentransfer literatur-literatur Islam klasik dan sebagai sarana membekali para santri dengan pemahaman warisan keilmuan masa lampau atau jalan kebenaran menuju kesadaran erotis ihwal status kehambaan/ubudiyah di hadapan Allah. ${ }^{28}$

Dengan kata lain, pengajaran kitab Islam klasik merupakan salah satu cara yang ditempuh oleh pesantren untuk membekali para calon ulama akan ilmu keislaman yang kelak akan ditransfer kepada masyarakat secara lebih luas.Adapun kitab klasik yang biasanya diajarkan di pondok pesantren salaf menurut Nurcholis Madjid digolongkan menjadi 7 kelompok yaitu: tauhid, akhlak, sintaksis (Nahwu) dan sorof (morfologi), fikih, hadis, dan Bahasa Arab. Selain itu, Dhofier menambahkan satu kelompok yaitu cabang-cabang kitab tarih dan balaghah. ${ }^{29}$

\section{Kesimpulan}

Sebagai sebuah lembaga yang bergerak dalam bidang pendidikan dan sosial keagamaan, pengembangan pesantren harus terus didorong untuk maju.Karena pengembangan pesantren tidak terlepas dari adanya kendala yang harus dihadapinya.Apalagi belakangan ini, dunia secara dinamis telah menunjukkan perkembangan dan perubahan secara cepat, yang tentunya, baik secara langsung maupun tidak langsung dapat berpengaruh terhadap dunia pesantren.Di era cepatnya perubahan di semua sektor dewasa ini, pesantren menyimpan banyak persoalan yang menjadikannya agak tertatih-tatih, kalau tidak malah kehilangan kreativitas, dalam merespon perkembangan zaman. Beberapa pesantren yang ada pada saat ini, masih kaku (rigid) mempertahankan pola salafiyah yang dianggapnya sophisticated dalam menghadapi persoalan eksternal. Padahal, sebagai suatu institusi pendidikan, keagamaan, dan sosial, pesantren dituntut melakukan inovasi dan internalisasi transformatif tanpa harus mengorbankan karakter nilai dasar aslinya.

\section{Daftar Pustaka}

Ridlwan Nasir, Mencari Tipologi Format Pendidikan Ideal Pondok Pesantren di Tengah Arus Perubahan, ( Yogyakarta; Pustaka Pelajar, 2005).

28 Said Aqiel Siraj, Pesantren Masa depan: wacana Pemberdayaan dan Transformasi pesantren, (Bandung: Pustaka Hidayah,1999), h. 16-17

${ }^{29}$ Nurcholish Madjid, Bilik-Bilik Pesantren..., h. 7-11

| RI'AYAH, Vol. 4 No. 01 Januari-Juni 2019 
Mohammad Fakry Gaffar, Internasionalisasi Program Pendidikan Guru dalam Hukum Manajemen Corporate dan Strategi pemasaran Jasa Pendidikan, (Jakarta; Alfabeta Bandung,2009).

Manfred Ziemek, Pesantren dalam Perubahan Sosial, (Jakarta;P3M,2005).

Lampung Post, Pendidikan Pesantren bangun Karakter, Rabu 18 juni 2014

Suyoto, Pondok pesantren dalam Alam Pendidikan Nasional (Jakarta; LP3S, 2005)

Dawam Rahardjo, Perkembangan Masyarakat dalam perspektif Pesantren, dalam Pergulatan Dunia Pesantren Membangun dari Bawah( Jakarta;P3M,2005),dan lihat Sudjoko Prasojo, Profil Pesantren (Jakarta; LP3S).

Dawam Raharjo, "Pesantren dan Pembaharuan", cet.V, (Jakarta; LP3ES, 1995).

Ridlwan Nasir, Mencari Tipologi Format Pendidikan Ideal Pondok Pesantren di Tengah Arus Perubahan, ( Yogyakarta; Pustaka Pelajar, 2005).

M. Ihsan Dacholfany, Pendidikan Karakter Belajar Ala Pesantren Gontor (Depok; Wafimediatama,2014).

UU Sisdiknas

Sanggar Kanto, Modernisasi dan Perubahan Sosial (Suatu Kajian dari Perspektif Teori dan Empirik). Malang: Fakultas Pertanian Universitas Brawijaya, 2006.

Malik, Jamaludin. Pemberdayaan Pesantren, Menuju Kemandirian dan Profesionalisme Santri dengan Metode Daurah Kebudayaan, Yogyakarta: Pustaka Pesantren, 2005.

Iskandar, Muhaimin. Gus Dur, Islam dan Kebangkitan Indonesia, Cet.I. Jakarta: Klik R. 2007

HM. Arifin, Hubungan Timbal Balik Pendidikan Agama, (Jakarta: Bulan Bintang, 1976). Ahmad D. Marimba, Pengantar Filsafat Pendidikan (Bandung: Al Ma'arif, 1989).

Soegarda Poerbakawatja, et. al. Ensiklopedi Pendidikan, (Jakarta: Gunung Agung, 1981).

Chabib Thoha, Kapita Selekta Pendidikan Islam, (Yogyakarta: Pustaka Pelajar, 2007)

Achmadi, Islam Sebagai Paradigma Ilmu Pendidikan, (Yogyakarta: Aditya media, 2007).

Ibrahim BR, "Filsafat Pendidikan Islam", Artikel dalam http://ibrahimbr. blogspot. com/ di download pada 02 Februari 2017

Nurcholish Madjid, Bilik-Bilik Pesantren sebuah Potret perjalanan, ( Jakarta: Paramadina, 1997).

Mastuhu, Dinamika sistem pendidikan Pesantren, (Jakarta:INIS,1994).

Martin Van Bruinessen, Kitab Kuning, Pesantren, dan Tarekat: Tradisi-tradisi Islam di Indonesia (Bandung: Mizan,1995).

Sulthon masyhud, Khusnur Ridho, Manajemen Pondok Pesantren,(Jakarta:Diva Pustaka, 2003).

Zamakhsyari Dhofier, Tradisi Pesantren Studi tentang Pandangan Hidup Kyai, (Jakarta: LP3S, 1983).

Abdullah Aly, Pendidikan Islam Multikultural di Pesantren, (Yogyakarta: Pustaka Pelajar, 2011).

Karel Steenbrink, Pesantren, Madrasah, dan Sekolah Pendidikan Islam dalam kurun Modern, (Jakarta: LP3ES,1986)

Said Aqiel Siraj, Pesantren Masa depan: wacana Pemberdayaan dan Transformasi pesantren, (Bandung: Pustaka Hidayah,1999). 